\title{
Potential Development of Retirement Village in Malaysia
}

\author{
Azlina Md. Yassin, Haidaliza Masram \& Ong Suet Khim \\ Faculty of Technology Management and Business, University Tun Hussein Onn Malaysia, 86400 Parit \\ Raja, BatuPahat, Johor, Malaysia \\ *Corresponding author: azlina@uthm.edu.my
}

\begin{abstract}
As life styles keep changing, people are now paying more attention towards their retirement life. The decision of where to live during their retirement life is related to many factors, such as financial resources, retirement timing and health status. Retirement village is a new concept in Malaysia as compared to the developed countries and there is still lack of public knowledge and awareness towards retirement village. In Malaysia, developers have cited lack of expertise, unfamiliarity with retirement village concept and high cost as constraints faced to build and manage retirement village. Therefore, the main objective of this paper is to study an awareness of the public towards retirement village concept in Malaysia. Through a survey conducted in Ipoh, the majority of the respondents prefer to stay at their own house after retirement rather than staying at retirement village. Moreover, respondents also indicated a medium level of acceptance towards potential development of retirement village concept in Malaysia, and the provision of 24 hours security and better healthcare were identified as the prominent services to be provided for the homes. It is hoped that the findings from this study would be useful to create awareness to the relevant stakeholders comprising local governments, developer and property investors for the purpose of retirement village development in the future.
\end{abstract}

Keywords: Awareness, Expectation, Public, Retirement village

\subsection{INTRODUCTION}

Ageing population is defined as a process by which older individuals takes on a larger share proportion of the total population (United Nations, 2013). Ageing population is considered as a global phenomenon and it is happening among the developed countries (Mclaughlin and Mills, 2008). Since the mid-twentieth century, the world population has been experiencing significant ageing where the proportions of older individuals keep on rising in the total population (United Nations, 2013). Malaysia is fast becoming a developed nation, and it is estimated to be an ageing nation by 2030. By 2030, Malaysia will have $14.2 \%$ of old age people and it is projected to reach $23.1 \%$ of old age people by 2050 (Global Age Watch, 2014). The reason behind of an ageing population in Malaysia is due to increase in life expectancy rate.

In general, basic needs for retirees after retirement are finance, housing, and health care. Living in retirement village is convenient as the residents can enjoy the facilities and the variety of social activities at the same times. Due to these factors, retirement village are now becoming accepted as a viable accommodation option as it can promote and enhance independence, choice and quality of life for elderly (Gardner et.al., 2005; Bernard et al, 2004; Jian et al, 2014). Various housing options are now available for the elderly, ranging from independent-living alternatives through to high-level care. Retirement villages have been widely accepted as a viable accommodation option, and are seen by a small but increasing number of retirees as a desirable and appropriate place to live after they retire (Stimson, 2002). 
Rapid national development programs, undertaken since independence, have resulted in increased income, better health, lower fertility, higher educational attainment, and increased life expectancy among the Malaysian population (Masud and Haron, 2014). As the financial ability of older people in Malaysia is increasing, therefore, a new and more comprehensive elderly care is seen as an emerging trend. Besides that, according to survey by Employment Provident Fund (EPF), Malaysian has low retirement savings due to high cost of living and wages stagnation problems (Melissa, 2014). Financial and health problem are the main worries of the retirees. In Malaysia, from July 12013 onwards, the minimum retirement age for most private-sector workers will be set at age 60 under the Minimum Retirement Age Act 2012. Until now, no statutory minimum age existed, but in practice most employers have set it at the age 55 for their employees.

Retirees have variety of options for retirement housing such as choose to live in own house, old folks homes, nursing home and more (Eldridge, 2010). Instead of living in their own houses or old folks homes, retirees can now live in retirement village. Retirement life is long, most people wish to enjoy their golden year in peace and joyful. Although retirement villages have been popular for decades overseas, retirement villages still face the problem such as lack of wide public knowledge of their existence or a real understanding on the wide range of benefits (Bailey, 2010). In Malaysia, developers have cited lack of expertise, unfamiliarity with retirement village concept and high cost as constraints faced by them to build and manage retirement village (Rajasakran, 2013). Therefore, this study is carried out with the aim to determine the perception of the concept and characteristic of retirement village as well as to study the awareness of the public towards retirement village.

\subsection{LITERATURE REVIEW}

\subsection{Elderly}

Elderly is defined as those who are aged 65 years and above, and this chronological age has been well accepted by most developed world countries. In Malaysia, elderly are defined as those who are 60 years and above (Ruhaini, 2013). The United Nations Resolution 35/129 of December 1980 endorsed the report for the World Assembly on the Elderly, in which the elderly population is defined as persons aged 60 and over. These countries use 65 years as the point of reference. However, this threshold is considered high in the developing countries as they are still beset with lower life expectancy. The developing countries, in general, accept 55 years as appropriate to distinguish the onset of old age.

\subsection{Ageing Population}

A population is also said to be ageing if it satisfies either one or both of the following two conditions (Yusnani, 2005). The first condition is when its average (mean or median) age increase above a certain threshold age. The second condition is the increase in the proportion of the population above a certain threshold age. Population ageing refers to the change in the balance among the age groups within the population, in particular among older age groups both absolutely and as a proportion of the population. Change is being generated by a combination of falling fertility and an increase in average life expectancy (Organisation for Economic Co-operation and Development (OECD), 1996). Following the definition of ageing of the United Nations (1993), a population is said to be ageing when more than seven percent comprise of people who are 60 years and above.

\subsection{Retirement}

The meaning of retirement normally will bond up with the receipt of a pension where precisely retirees are known as pensioners (Berry, 2010). In the UK context, there is a definition of retirement in common use. It is commonly considered that a person is retired if she or he is drawing a pension. Retirement can be simplistically understood as an event such as the day when a person ceases 
a lifetime of paid employment and begins living on their pension. Similarly, retirement may be seen as a state of being, or fairly stable stage in life.

\subsection{Existing Accommodation for Elderly in Malaysia}

Accommodation for the elderly is defined as housing where an elderly person is sheltered and the level of care provided within a setting (Yusnani, 2005). Sulaiman et. al (2006a) identified care homes for the elderly in Malaysia are provided by three main parties. They are the government or public sector provider known as Department of Social Welfare (DSW), the non-governmental organizations (NGOs) which respond to the needs of older people as well as to the encouragement by the government, both of this is non-profit oriented whereas for the private sector, it is a profit oriented in which the ability to pay applies.

In Malaysia, a review made by Sulaiman et. al (2006a and 2006b) have shown that public or private sector developer has not provided the housing schemes for the elderly. Basically, housing units in Malaysia are developed based on general family needs instead of special needs. Through this evidence, it shows that the government lacked in intention to fullfill the requirements of people with special needs. Unfortunately, in Malaysia, there is no legislation that requires housing developers to design and build their housing scheme to emphasise the needs of the elderly.

Existing formal institutional care homes for elderly can be divided into three categories; namely residential care home for the elderly, nursing care home for the elderly and day care centre. The provision of care homes for the elderly in Malaysia is considered as a social policy program under the community and family development allocation. The provision of care homes for the elderly is managed by the Ministry of Women, Family and Community Development (MWFCD). Under MWFCD, the care homes for the elderly in Malaysia are managed by Department of Social Welfare (DSW).

\subsection{Development of Retirement Village}

In a study by Paris (2010), retirement village is defined as a place for people aged 55 and over. The village offer housing in a secured development, often with gates or restricted access. Residents have their own front door, a range of facilities and social activities alongside a range of care and support services that can cater for a person's health and care needs as they get older. Mccullagh (2014) assert a retirement village should consist of three social features such as only residents who age of 55 years or retired from full-time work, or the spouse or domestic partner if such a person can stay in retirement village, the retirement villages should provide recreational facilities and various care services to residents.

Retirement villages are also known as retirement communities and care villages. These are formed as part of a large group of retirement or sheltered housing schemes for seniors. Essentially anything from an estate to a full blown village-sized retirement development of bungalows, flats or houses, intended for occupation by older people; often include a number of recreation facilities, and sometimes a care home. These retirement communities for seniors exist in the public, voluntary and private sectors, and are provided by local authorities, housing associations, private companies, charities and trusts, or by a combination of these. Basically, retirement villages cater mainly for people who are able to live independently. Some retirement villages provide aged care facilities on the same site or an adjacent site. In this situation, if resident's health is reduced, they can move and stay in aged care facilities. 


\subsection{Model of Retirement Villages}

There are several models of retirement villages, but only two types of models will be discussed in this paper, since these two models are more common and they are (i) Continuing Care Retirement Community(CCRC), (ii) Village Model.

\section{(i) Continuing Care Retirement Community $(C C R C)$}

Since the mid-1980s, CCRCs have evolved and diversified dramatically, emerging from traditional religious and community-based models. CCRCs combine the provision of housing and care (Rogers, 2011). CCRCs offer their residents more service packages and entrance-fee options. CCRCs generally feature a combination of independent living apartments and/or cottages and nursing care, and many offer assisted living, memory support care, and other specialty care arrangements. They also provide residents with 24-hour security, social and recreational activities, attractive dining options, housekeeping, transportation, and wellness and fitness programs.

Village model is a non-governmental approach. Villages represent an emerging consumer-driven social support model that aims to enhance the social engagement, independence, and well-being of community-dwelling seniors through a combination of social activities, volunteer opportunities, service referral, and direct assistance. Furthermore, villages are an innovative type of grassroots organisations that have emerged in the past decade in the organizational field of support services for community-dwelling older adults. The village model strives to support social connections and increase independence by facilitating access to both volunteer assistance and existing services in the community (Graham et.al., 2014). Most villages are consumer driven and initiated, developed, and have ongoing input from adult members (Greenfield et al, 2012). Usually the villages are selfgoverning and independent.

\subsection{Types of retirement villages}

According to Elliott et.al. (2002), basically there are two types of retirement villages:

(i) Donor-funded villages are funded by way of charitable and/or government contributions. The residents need to make donations on entering the village, such donation being nonrefundable.

(ii) Resident-funded villages, as the name suggests are villages whose total capital expenditure is obtained from residents by way of ingoing payments for the "purchase" of self-care units or assisted apartments occupied, with such ingoing payments being refundable in full or in part in accordance with the resident's contract at the commencement of occupation.

For both categories of retirement village and in addition to any donation or ingoing payment made by a resident, ongoing weekly (in some cases monthly) service fees are paid by the residents. Such fees are for the 'daily' running expenses of the village. Normally, these fees vary from village to village, and depend on the quality of services and care provided, which include the type of housing occupied. In addition, the service fee covers expenses such as maintenance of grounds, external property maintenance, property insurance, rates and taxes, administration costs, wages of staff and many more.

In general retirement villages can provide a range of accommodation services for the elderly, which are generally categorized as independent living units (villas), serviced apartments and nursing home/care home. 


\subsection{Benefits of Living in Retirement Village}

There are several benefits that can be provided by a retirement village. Most of the retirement village highly promote independence living as this is can enable the elderly for independence living. Independant living has been considered as an important requirement for health and general well-being (Ball and Nanda, 2013). In addition, retirement village can help the elderly to achieve ageing in place as well. Furthermore, facilities and social activities that are provided in retirement village enable elderly provide the opportunity to meet and socialize with other residents. Social connections can help elderly to obtain happiness, healthy life and longevity. In retirement village, elderly can also enjoy different type of facilities and services. Facilities such as library, gymnasium, swimming pool, computer room and others can be enjoyed by elderly in a short distance from where they live. In addition the elderly can enjoyed variety types of services such as laundry service, meal delivery, transports to send elderly go to the place they wish and more. Elderly can also receive personal and medical care in retirement village. Lastly, retirement village provide 24 hours security to their residents.

\subsection{Concept of Retirement Village in Malaysia}

Currently, there is no clear and legal definition regarding retirement village in Malaysia as it is still is a new concept in Malaysia. A retirement village enables elderly to live independently (Chua, 2014). Retirement villages can be in the form of multigenerational homes, high density residences or retirement resorts. With integration of senior friendly designs and support services in a retirement villages allow the elderly to maintain their lifestyle in their own homes even with increasing disability (Rajasakran, 2013).

\subsection{Experience of Retirement Village in Malaysia}

Currently in Malaysia, there are two retirement villages. One is named as the GreenAcres Retirement Home which are located in Ipoh, Perak, and the other one is Eden-on-the-Park which is located in Kuching, Sarawak. Both retirement villages were developed based on Australia retirement village concept. Both of the retirement village has just been completed in 2017. A summary of the features of these two villages are shown in Table 1 below.

Table 1: Summary of Experience Retirement Village in Malaysia

\begin{tabular}{|c|c|c|}
\hline Case Study & The GreenAcres Retirement Home & The Eden-on-the-Park \\
\hline Type & Resident funded & Resident funded \\
\hline Model & $\begin{array}{l}\text { Continuing Care Retirement } \\
\text { Community (CCRC) }\end{array}$ & $\begin{array}{l}\text { Continuing Care Retirement } \\
\text { Community (CCRC) }\end{array}$ \\
\hline $\begin{array}{l}\text { Minimum age for } \\
\text { elderly to enter }\end{array}$ & 55 years old and above & 55 years old and above \\
\hline Tenure & Leasehold & Freehold \\
\hline Amenities facility & $\begin{array}{ll}\text { - } & \text { Clubhouse } \\
\text { - } & \text { Aged care }\end{array}$ & $\begin{array}{ll}\text { - } & \text { Clubhouse } \\
\text { - } & \text { Aged care } \\
\end{array}$ \\
\hline Services & $\begin{array}{ll}\text { - } & \text { Housekeeping } \\
\text { - } & \text { Laundry services } \\
\text { - } & \text { Transportation provided } \\
\text { - } & \text { Meal delivery } \\
\text { - } & \text { Personal care and medical care etc }\end{array}$ & $\begin{array}{ll}\text { - } & \text { Housekeeping } \\
\text { - } & \text { Laundry services } \\
\text { - } & \text { Transportation provided } \\
\text { - } & \text { Meal delivery } \\
\text { - } & \text { Personal care and medical } \\
& \text { care etc }\end{array}$ \\
\hline Management & $\begin{array}{l}\text { - A capital sum is collected from } \\
\text { residents when they enter. } \\
\text { - Monthly service fee (including } \\
\text { maintenance fee) is collected from }\end{array}$ & $\begin{array}{l}\text { - A capital sum is collected } \\
\text { from residents when they } \\
\text { enter. } \\
\text { - Monthly service fee }\end{array}$ \\
\hline
\end{tabular}




\begin{tabular}{|c|c|c|}
\hline & $\begin{array}{l}\text { residents based on the size of } \\
\text { accommodation. } \\
\text { - Deferred Management Fee (DMF) } \\
\text { at } 3 \% \text { per annum is collected from } \\
\text { residents when they leave. } \\
\text { - After deducting DMF from capital } \\
\text { sum, the remaining fund will be } \\
\text { refunded to residents. }\end{array}$ & $\begin{array}{l}\text { (including maintenance fee) } \\
\text { is collected from residents } \\
\text { based on the size of } \\
\text { accommodation. } \\
\text { No DMF is collected from } \\
\text { residents for freehold tenure. }\end{array}$ \\
\hline $\begin{array}{l}\text { Legislation regarding } \\
\text { retirement village }\end{array}$ & $\begin{array}{l}\text { - None, however an Aged } \\
\text { Healthcare Act is being proposed } \\
\text { to set up legal standard for } \\
\text { develop retirement village and } \\
\text { aged care facility. } \\
\text { - For now, Greenacres register and } \\
\text { follow standard under Care Center } \\
\text { Act. }\end{array}$ & 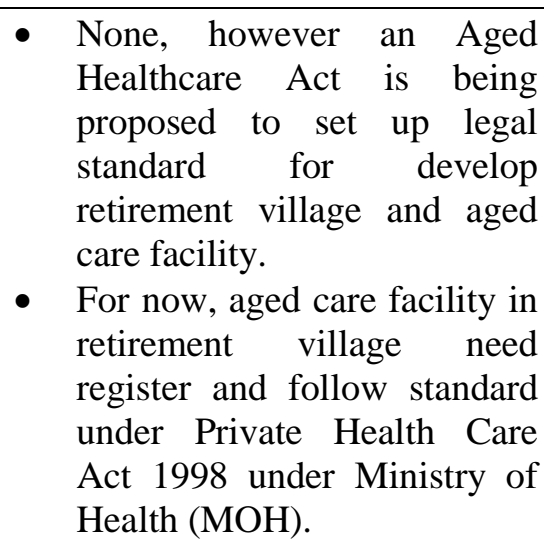 \\
\hline
\end{tabular}

In order to gauge the awareness of retirement home concept in Malaysia, Ipoh city has been selected to gather the perception of the people on retirement home concept. Ipoh city was chosen as the study area for this study as it has one of the prominent retirement village as described above. The first phase of greenacres retirement home was officially unveiled in October 2017 and officiated by Datuk Seri Mah Siew Keong.

\subsection{METHODOLOGY}

In this research, a quantitative research strategy has been adopted in which a survey was conducted amongst the people in the selected city. From a purposive sampling of 204 people within Ipoh city that were asked to participate in the survey, 153 participants responded, accounting to $75 \%$ response rate. The study was conducted within Ipoh City, which is located in Perak state, Malaysia. As the capital city of Perak state, it is one of the largest cities in Malaysia. It has a population of 700,000 people and according to the Department of Statistic Malaysia, the distribution of the population in Ipoh is Chinese comprising $44.1 \%$, followed by Bumiputera at $38.5 \%$, Indian at $14.1 \%$ and others at $3.2 \%$. In addition, Ipoh was announced as one of the nine best affordable places to retire in the world in 2014. The survey was conducted to gauge the awareness and tendency of those living in Ipoh city to retirement home living. 


\subsection{RESULTS AND DISCUSSION}

\subsection{Respondents' Profile}

Table 2 below shows the respondent profile participated in this study.

Table 2: Respondents' Profile

\begin{tabular}{|l|c|}
\hline \multicolumn{1}{|c|}{ Respondent profile } & Frequency (Percentage \%) \\
\hline Gender: & $65(57.52)$ \\
Male & $88(42.48)$ \\
Female & \\
\hline Race: & $50(32.68)$ \\
Malay & $73(47.41)$ \\
Chinese & $22(14.38)$ \\
Indian & $8(5.23)$ \\
Others & \\
\hline Age: & $48(31.37)$ \\
25 - 34 years old & $36(23.53)$ \\
35-44 years old & $30(19.61)$ \\
45-54 years old & $24(15.69)$ \\
$55-64$ years old & $15(9.80)$ \\
Above 65 years old & \\
\hline Marital Status: & $80(52.29)$ \\
Single & $58(37.91)$ \\
Married & $15(9.81)$ \\
Divorced & \\
Income: & $23(15.03)$ \\
Below RM1500 & $39(25.49)$ \\
RM1,501 - RM3000 & $60(39.22)$ \\
RM3,001 - RM5000 & $26(16.99)$ \\
RM5,001 - RM10000 & $5(3.27)$ \\
Above RM10, 001 & \\
\hline Types of housing after retirement: & $120(78.43)$ \\
Own house & $8(5.23)$ \\
Old folks home & $7(4.58)$ \\
Nursing home & $15(9.80)$ \\
Retirement village & $3(1.96)$ \\
Others & \\
\hline Awareness of Retirement Village: & $49(32.01)$ \\
Have heard of it & $104(67.97)$ \\
Have not heard of it & $20(13.07)$ \\
\hline Entrance Age of Retirement Village: & $87(56.86)$ \\
50 - 55 years old & $46(30.07)$ \\
56 - 60 years old & \\
Above 65 years old & \\
\hline
\end{tabular}

Note: $\mathrm{n}=153$

The majority of the respondents are from the younger age range and have income levels of RM3,000 to RM5,000. When the respondents were asked on the retirement home that they would consider, $78.4 \%$ have responded by stating their own homes as the option. Majority of the respondents are not aware of retirement homes and they have stated that the entrance age of retirement village to be from the age 56-60 years old. 


\subsection{Benefit of Retirement Village}

From the results, the tendency level of the benefits of living in retirement village has been determined and they are shown in Table 3 below.

Table 3: Benefits of Retirement Village

\begin{tabular}{|c|l|c|c|}
\hline Nos & \multicolumn{1}{|c|}{ Benefit } & Mean Score & Tendency Level \\
\hline 1. & Enable elderly to live independently & 3.37 & Medium \\
\hline 2. & Helps to promote ageing in place concept. & 3.52 & Medium \\
\hline 3. & Helps in improving elderly quality of life. & 3.53 & Medium \\
\hline 4. & $\begin{array}{l}\text { Helps elderly to obtain happiness, healthy life and } \\
\text { longevity through social activities }\end{array}$ & 3.50 & High \\
\hline 5. & $\begin{array}{l}\text { Enjoy plenty of facilities and services in } \\
\text { retirement village }\end{array}$ & 3.74 & Medium \\
\hline & \multicolumn{1}{|c|}{ Total Mean Score } & $\mathbf{3 . 5 3}$ & \\
\hline
\end{tabular}

Note: High= 3.67 -5.00; Medium $=2.24-3.66 ;$ Low $=1.00-2.33$

The results show the medium level of respondents' acceptance towards benefits of living in retirement village. From the results, majority of the respondents agreed that by living in retirement village an elderly can enjoy plenty of facilities and services (mean score $=3.74$ ) which are provided in retirement village. The findings indicated that the public mainly perceived retirement village as a place that provides facilities. However, lowest mean score showed that the respondents do not seem to agree that retirement village would enable the elderly to live independently in retirement village.. These results showed there is lack of awareness among the public on the understanding of the benefits of living in a retirement village.

\subsection{Public Expectation towards Retirement Village Concept}

Based on the results, most of the respondents were in agreement that the retirement village should be provided with 24 hours emergency response system in each unit (mean score $=4.36$ ). On the other hand, the price unit in retirement village (paying the fee) has the least level of acceptance by the public (mean score $=2.83$ ). The overall results of the public expectation of the retirement village concept are shown in Table 4 below.

Table 4: Public Expectation towards Retirement Village Concept

\begin{tabular}{|c|c|c|c|}
\hline Nos & $\begin{array}{l}\text { Expectation } \\
\end{array}$ & Mean Score & Tendency Level \\
\hline 1. & $\begin{array}{l}\text { The price unit should be in the range of RM300k to RM } \\
1.2 \text { million. }\end{array}$ & 2.83 & Medium \\
\hline 2. & $\begin{array}{l}\text { In a unit, the number of bedroom should consist of one or } \\
\text { two bedroom. }\end{array}$ & 3.63 & Medium \\
\hline 3. & $\begin{array}{l}\text { All the community facilities should be included in the } \\
\text { clubhouse. }\end{array}$ & 3.74 & High \\
\hline 4. & $\begin{array}{l}\text { The design and furniture of the unit should be user } \\
\text { friendly. }\end{array}$ & 4.16 & High \\
\hline 5. & $\begin{array}{l}\text { The retirement village should provide village bus to their } \\
\text { residents. }\end{array}$ & 4.12 & High \\
\hline 6. & $\begin{array}{l}\text { A retirement village should provide aged care facilities to } \\
\text { their residents. }\end{array}$ & 4.21 & High \\
\hline 7. & Retirement village should be a gated community. & 4.10 & High \\
\hline 8. & $\begin{array}{l}\text { Retirement village should be provided } 24 \text { hours } \\
\text { emergency response system in each unit. }\end{array}$ & 4.36 & High \\
\hline 9. & Residents should be able to have pets in their own unit. & 3.44 & Medium \\
\hline 10. & $\begin{array}{l}\text { The form of tenure should be either leasehold or } \\
\text { freehold. }\end{array}$ & 3.44 & Medium \\
\hline 11. & Social activity should be provided for residents in a & 3.97 & High \\
\hline
\end{tabular}


e-issn: $2229-8568$

\begin{tabular}{|c|c|c|c|}
\hline Nos & \multicolumn{1}{|c|}{ Expectation } & Mean Score & Tendency Level \\
\hline & retirement village. & & \\
\hline & \multicolumn{2}{r|}{ Total Mean Score $=3.82$} & High \\
\hline
\end{tabular}

Note: High $=3.67-5.00 ;$ Medium $=2.24-3.66 ;$ Low $=1.00-2.33$

From the results, the respondents had expected that retirement village will provide 24 hours emergency response system considering the declining health or disability of elderly. 24 hours emergency response system is needed as elderly living in independent units. Apparently, when $\mathrm{n}$ the alarm is made through the emergency button, village management are to send assistance to help the elderly. This criteria was also highlighted by Ball and Nanda (2013) as an important criteria while planning retirement home. In addition, elderly need other facilities, services and social activity as well on order to fulfill their needs. However, for the price units offered by retirement village, it is perceived that the elderly may not be able to afford to pay the payment. Therefore this expectations gathered the lowest mean among the others.

\subsection{Public Perception towards the Potential of Retirement Village Development in Malaysia}

With regards to the potential of retirement village development in Malaysia, the respondents indicated medium level of tendency with an average mean score is 3.51. This result shows that the retirement village has the potential to be built in the future. Majority respondents perceived that the retirement village should provide a better health care for the elderly (mean score $=3.82$ ). Nevertheless, the statement of retirement village as a good housing option for respondent parents in the future showed the lowest mean score of 3.06. Table 5 shows the overall results from the respondents.

Table 5: Public Perception towards the Potential of Retirement Village Development

\begin{tabular}{|c|l|c|c|}
\hline Nos & \multicolumn{1}{|c|}{ Potential } & Mean Score & Tendency Level \\
\hline 1. & $\begin{array}{l}\text { Retirement village would be a better option for elderly in } \\
\text { Malaysia if compared to conventional old folk's homes. }\end{array}$ & 3.67 & High \\
\hline 2. & $\begin{array}{l}\text { Retirement village would provide a better health care for the } \\
\text { elderly. }\end{array}$ & 3.82 & High \\
\hline 3. & $\begin{array}{l}\text { Retirement village would promote a better quality of life for } \\
\text { the elderly. }\end{array}$ & 3.73 & High \\
\hline 4. & $\begin{array}{l}\text { Retirement village would be a good housing option for you in } \\
\text { the future? }\end{array}$ & 3.27 & Medium \\
\hline 5. & $\begin{array}{l}\text { Retirement village would be a good housing option for your } \\
\text { parents in the future? }\end{array}$ & 3.06 & Medium \\
\hline & \multicolumn{2}{|r}{ Total Mean Score =3.51 } & \multicolumn{2}{|r}{} \\
\hline
\end{tabular}

From the results, there is a high level of tendency shown by the respondents of the potential for the development of retirement village in the future. From the preliminary survey made in this study, it can be shown that there respondents have given agreement that retirement village would provide a better health care for the elderly and promote a better quality of life for elderly. However, they did not view retirement village as a good option for their parents and themselves. Majority of the respondents prefer to stay at their own home after retirement as compared to retirement village.

\subsection{CONCLUSION}

The main objective of this paper is to study the perception of the public towards retirement village development concept in Malaysia. In a survey undertaken in Ipoh, the respondents provided varying responses. From the results, majority of respondents have not heard about retirement village in Malaysia which accounted for $67.97 \%$. In addition, less than 50\% of respondent have heard about retirement village, and only one third of them were willing to stay in retirement village rather than their own home. The findings indicated that the public mainly perceived retirement village as a place 
that provides facilities. Furthermore, the respondents perceived that the retirement village concept should be provided with 24 hours emergency response system in each unit as well as providing aged care facilities to their residents. This result also disclosed that the retirement village has the potential to be built in the future. It is hoped that the results of this study provide some form of indicator on the awareness of public towards the development of retirement village and its development concept to the various stakeholders namely the Local Government, developers and property investors.

\subsection{REFERENCES}

1. Bailey, L. (2010). UK Retirement Housing Report-2010. Knight Frank. Retrieved on April 7, 2015 from: http://www.knightfrank.co.uk/news/knight-frank-retirement-housing-report-20100123.aspx.

2. Ball, M. \& Nanda, A. (2013). Household attributes and the future demand for retirement housing. International Journal of Housing Market and Analysis, Vol. 6(1), pp. 45-62. Emerald Group Publishing Limited.

3. Bernard, M., Bartlam, B., Biggs, S. \& Sim, J. (2004). New Lifestyles in Old Age, Health, Identity and Well-Being in Berryhill Retirement Village. The Policy Press, Bristol.

4. Berry, C. (2010). The Future of Retirement. Retrieved on April 5, 2015, from: http://www.ilcuk.org.uk/.../pdf_pdf 134

5. Paris, C. (2010). The Future Housing and Support Needs of Older People in Northern Ireland. Report to the Northern Ireland Housing Executive, November 2010. Retrieved on April 16, 2015 , from: http://www.nihe.gov.uk/analysis_of_the_future_need_and_demand_for_appropriate_models of_accommodation_and_associated_services_for_older_people_published_february_2011_.p $\underline{\mathrm{df}}$

6. Chua, H. T. (2014). The Post Retirement Life. The Star Online. September 6, 2014. Retrieved on May 3, 2015,from: http://www.thestar.com.my/Business/Business-News/2014/09/06/Thepostretirement-life/?style=biz

7. Eldridge, L. K. (2010). Baby Boomer's Needs and Preferences for Retirement Housing: A Phenomenological Quantitative Study. Retrieved on March 26, 2015, from: Pro Quest database.

8. Elliott, P., Earl, G., \& Reed, R. (2002) . The Valuation of Self-funded Retirement Villages In Australia: Analysis, Reliability And Investment Valuation Methodology. Pacific Rim Real estate Society Conference, 21 - 23 January 2002, Christchurch, New Zealand. Retrieved on May 4, 2015, from: http://www.prres.net/Papers/Elliott_Valuation_of_self_funded_retirement_villages_in_Austral ia.pdf

9. Gardner, I. L., Browning, C. \& Kendig, H. (2005). "Accommodation options in later life: Retirement village or community living?". Australasian Journal on Ageing, Vol. 24 No. 4, pp. 188-195.

10. Global Age Watch. (2014).Retrieved March 12, 2015, from http://www.helpage.org/globalagewatch/population-ageing-data/country-ageing data/?country=Malaysia. 
11. Graham,C. L., Scharlach, A, E. \& Wolf, J. P. (2014) . The Impact of the "Village" Model on Health, Well-Being, Service Access, and Social Engagement of Older Adults. Health Education \& Behaviour, Vol. 41. National Library of Medicine, USA.

12. Greenfield, E. A., Scharlach, A. E., Graham, C., Davitt, J., \& Lehning, A. (2012). A National Overview of Villages: Results from a 2012 Organizational Survey. Rutgers School of Social Work, the State University of New Jersey. Retrieved from: http://www.ageingandcommunity.com/wp-content/uploads/2012/12/Village-FINAL.pdf

13. Jian, Z, Bo, X., Jake, B., \& Skitmore, M. (2014). Green Buildings for Greying People: A Case Study of a Retirement Village in Australia. Emerald Insight. Retrieved April 3, 2015, from: http://www.researchgate.net/publication/264497432_Green_buildings_for_greying_people_A case study of a retirement village in Australia

14. Mccullagh, R. (2014). Care in Australian Retirement Villages. Elder Law Review. Retrieved on April 8, 2015, from: http://www.uws.edu.au/_data/assets/pdf_file/0006/733776/McCullagh_04.pdf

15. McLaughlin, T. \& Mills, A. (2008). "Where will we live when we get older?", Quality in Ageing and Older Adults, Vol. 9 (3). pp. 15 - 21. Retrieved on March 2, 2015, from: Emerald Insight database.

16. Masud J \& Haron S A (2014), Income Disparity among Older Malaysians, Research in Applied Economics, Vol 6(2), pg. 117. Macrothink Institute.

17. Melissa, C. (2014) . Retirement crisis brewing as EPF savings suggest pensioner poverty. The Malay Mail. Retrieved on March 11, 2015,from: http://www.themalaymailonline.com/malaysia/article/retirement-crisis-brewing-as-epfsavings-suggest-pensioner-poverty

18. Organisation for Economic Co-operation and Development (OECD) (1996). Annual Report for 1996. Retrieved on May 1, 2015, from: http://www.oecd.org/about/34711139.pdf

19. Paris, C. (2010) Analysis of the future need and demand for appropriate models of accommodation and associated services for older people. Northern Ireland: Northern Ireland Housing Executive. Available at: http://www.nihe.gov.uk

20. Rajasakran, T. (2013, Nov 17), Retirement Village the Way Forward, News Straits Times

21. Rogers, R. (2011). Planning and Delivering Continuing Care Retirement Communities. Tetlow King Planning Ltd. Retrieved on May 4, 2015, from: http://www.southoxon.gov.uk/sites/default/files/SODC_26a.pdf

22. Ruhaini, Z. (2013). Active ageing in Malaysia. The Second Meeting of the Committee on International Cooperation on Active Aging, 13 July 2013, Tokyo, Japan. Retrieved on April 25, 2015, from: $\quad$ http://www.mhlw.go.jp/stf/shingi/2r98520000036ylaatt/2r98520000036yqa 1.pdf

23. Stimson, R. (2002). The Retirement Village Industry in Australia: Evolution, Prospects, Challenges, University of Queensland Press, Brisbane. 
24. Sulaiman, Mat Radzuan,I., Baldry, D. \& Ruddock, L. (2006a). Issues and Challenges on the Provision of Housing for the Elderly in Malaysia. Proceedings of the ASEAN Healthy City Conference on March 28, 2006, Putrajaya, Malaysia.

25. Sulaiman, Mat Radzuan,I., Baldry, D. \& Ruddock, L (2006b). 'Issues Concerning Housing for the Elderly in Malaysia'. Proceedings of the $6^{\text {th }}$ International Postgraduate Research Conference on April 6-7, 2006, Delft University of Technology.

26. United Nations (1993). World Population Prospects, United Nations, New York.

27. United Nations (2013). World Population Ageing Report 2013. United Nations, New York.

28. Yusnani, M. Y. (2005). What Should Happen to the Future Accommodation of the Elderly in Malaysia?. School of Geography, Planning and Architecture, University of Queensland, Australia. Retrieved on April 12, 2015, from: http://www.ubd.edu.bn/academic/faculty/FASS/staff/docs/YM/yusnani-phd.pdf 